\title{
Trauma-induced coagulopathy. A narrative review of goal-directed hemostatic resuscitation
}

\author{
Federica Pigna, ${ }^{1}$ Giuseppe Lippi, ${ }^{2}$ Simone Saronni, ${ }^{3}$ Gianfranco Cervellin ${ }^{1}$ \\ ${ }^{1}$ Emergency Department, University Hospital of Parma, Parma; ${ }^{2}$ Section of Clinical Biochemistry, \\ University of Verona, Verona; ${ }^{3}$ Emergency Department, Fondazione IRCSS Ca' Granda, Ospedale Maggiore \\ Policlinico, Milan, Italy
}

\begin{abstract}
Post-traumatic haemorrhage is the leading cause of death in trauma patients. The development of coagulopathy substantially contributes to bleeding severity and to the ensuing unfavourable outcome. Trauma-induced coagulopathy (TIC) can be seen in 10$25 \%$ of patients with major trauma, and its early and appropriate therapeutic management leads to considerable reduction of mortality risk. Due to the extreme complexity of TIC pathophysiology, the limitations of conventional coagulation tests (CCTs) have become evident in recent years. Unlike these routine tests, point of care viscoelastic tests (VET) such as thromboelastogram (TEG) or rotational thromboelastography (ROTEM) provide valuable clinical information by real time assessment of changes in viscoelastic properties of blood throughout clot formation. This review was aimed to collect and discuss available evidence on goal-directed hemostatic resuscitation, based on TEG or ROTEM data. We included studies with patients aged 18 years or older, major trauma, and needing massive transfusions. Overall, 6 studies totalling 1533 patients were finally included. A total number of 288 patients died, 98 of whom in the TEG- or ROTEM-guided cohorts (i.e.,
\end{abstract}

Correspondence: Gianfranco Cervellin, Emergency Department, University Hospital of Parma, Via Gramsci 14, 43126 Parma, Italy.

E-mail: gcervellin@ao.pr.it

Key words: Trauma; Coagulopathy; Thromboelastography; Thromboelastometry; Thromboelastogram; Rotational thromboelastography.

Contributions: FP and GC made bibliographic research and wrote the manuscript; SS and GL made statistical analysis; all the authors reviewed the manuscript.

Conflict of interest: the authors declare no potential conflict of interest.

Funding: none.

Received for publication: 18 May 2018.

Revision received: 27 August 2018.

Accepted for publication: 3 October 2018.

This work is licensed under a Creative Commons Attribution 4.0 License (by-nc 4.0).

CCopyright F. Pigna et al., 2018

Licensee PAGEPress, Italy

Emergency Care Journal 2018; 14:7569

doi:10.4081/ecj.2018.7569 intervention groups). A 36\% reduction of death was observed in the intervention groups (relative risk, $0.641 ; 95 \%$ CI 0.517-0.795; $\mathrm{P}<0.001$ ). Our results show that VET-guided management is effective to reduce mortality compared to conventional management with CCTs. Except for mortality, all others endpoints were heterogeneous across the studies. This emphasize the need of scheduling new and well-designed trials, aimed to better define the optimal strategy for TIC management.

\section{Introduction}

Physical injuries, especially those attributable to road traffic accidents, are a leading cause of death and morbidity worldwide, accounting for up to 1.5 million annual deaths and thus representing the most common cause of death for subjects aged between 15 to 49 years. $^{1-3}$ The 2002-2004 mortality data from National Statistical Authorities in the 272 European Union regions attests that $6.9 \%$ and $3.5 \%$ of all deaths in men and women, respectively, were caused by injuries. Nearly $22 \%$ of all these fatal injuries could be attributable to transport accidents, especially road traffic crashes, whilst $19.4 \%$ of all injury deaths were actually due to accidental falls. ${ }^{4}$

Post-traumatic haemorrhage is the leading cause of death in trauma patients. The development of coagulopathy consistently contributes to the bleeding severity and to the ensuing unfavourable outcomes. ${ }^{5}$ Trauma-induced coagulopathy (TIC) can be seen in $10-25 \%$ of patients with major trauma, and its early and appropriate management leads to a substantial reduction of mortality risk. ${ }^{6-9}$ The aetiology of TIC has been a matter of speculation for long. The rather simplistic theory, widely acknowledged as the lethal triad theory (i.e., including hypothermia, hemodilution and acidosis), seems insufficient to fully explain the large array of pathophysiologic mechanisms underlying the early and late coagulopathy that often develop after major trauma. ${ }^{9,10}$ Several factors, such as hypofibrinogenemia, release of prothrombotic substances (namely tissue factor) and activation of blood coagulation, consumption or dilution of clotting factors, platelet dysfunction, disseminated intravascular coagulation (DIC) and hyperfibrinolysis have all been implicated. ${ }^{11-15}$ Nevertheless, TIC is currently regarded as a multifactorial condition, which results from a combination of tissue injury and hypo-perfusion. ${ }^{9,11}$ Shock is seemingly the main trigger, whilst the occurrence of tissue damage is a pre-requisite for the onset of TIC. After development and worsening of shock, fluid resuscitation is a mainstay of management, but it further promotes hemodilution, which in turn exacerbates the preexisting coagulation abnormalities. When bleeding cannot be efficiently arrested or controlled, hypothermia and acidosis also develop, thus further worsening the coagulopathy, and possibly triggering DIC, the presence of which characterizes the worst form of 
TIC. A vicious circle, often leading to patient death, is then established. ${ }^{16}$ Tissue inflammation has also been studied as a contributing factor, but evidence on its real contribution to the pathogenesis of TIC remains elusive. ${ }^{13,17,18}$

TIC usually develops very early, within few minutes after trauma, and this would rule out that the lethal triade should be regarded as a pivotal factor, at least in the earliest phases. Floccard et al. collected blood samples from 45 major trauma patients on the scene, followed by further sampling in the Emergency Department (ED). The authors could identify the presence of coagulation abnormalities in $56 \%$ of patients within 25 min from the event, and in as many as $60 \%$ of them upon ED admission, which would lead to conceive that TIC may not always be a consequence of fluid resuscitation. ${ }^{19}$

TIC is also an independent risk factor for early death, need of blood transfusion, thrombosis and sepsis. ${ }^{9,20}$

Due to the extreme complexity of TIC pathophysiology, the limitations of conventional coagulation tests (CCTs), such as prothrombin time/international normalized ratio, activated partial thromboplastin time, platelet counts and fibrinogen, have become evident in recent years. ${ }^{21}$ Unlike these routine laboratory tests, point of care viscoelastic tests (VET) such as thromboelastogram (TEG) or rotational thromboelastography (ROTEM) can provide valuable clinical information by real time assessment of changes in viscoelastic properties of blood throughout clot formation, thus overcoming the many inherent limitations of CCTs (i.e., they only provide information on limited aspects of primary or secondary hemostasis and do not actually mirror clot stability and fibrinolysis). ${ }^{22,23}$ Since blood coagulation is assessed at the bedside rather than with central lab testing, the turnaround time is also consistently shortened using VET. Moreover, TEG and ROTEM are whole blood-based tests, so that they allow investigating the intricate interplay between clotting factors and blood cells, especially platelets (i.e., between primary and secondary hemostasis). The results are generated with a graphic layout and in real time, throughout clot development, at body temperature. 22,24 Based on this evidence, it has recently been suggested that VETs may replace CCTs for guiding blood component transfusion in trauma patients. ${ }^{25}$ Beside trauma-care, these tests are now frequently used in many cardiothoracic surgery or organ transplant centres, where they allow a substantial saving of blood derivatives, and enable achieving better clinical outcomes. ${ }^{26}$

Three main strategies are currently used for managing severe bleeding in trauma patients, i.e., i) the hemostatic resuscitation; ii) the goal-directed hemostatic resuscitation approach; iii) the Copenhagen Concept.

Hemostatic resuscitation encompasses an early transfusion strategy based on a fixed erythrocytes:plasma:platelets ratio of $1: 1: 1$, aimed to avoid the so-called dilutional coagulopathy. ${ }^{6}$ The Prospective, Observational, Multicenter, Major Trauma Transfusion (PROMMTT) study showed a reduction in mortality, as well as an early achievement of higher plasma and platelet ratios in patients receiving transfusions of at least 3 units of blood products during the first 24 hours after admission. ${ }^{27}$ The same Authors, arguing whether or not the 1:1:1 ratio is the optimal resuscitation strategy for all seriously injured patients, have hence planned the only randomized prospective study available so far to test this hypothesis. In the PROPPR Trial, the 1:1:1 and 1:1:2 (plasma, platelets, red blood cells) ratios were compared. Notably, no significant difference was observed for 24 hours mortality rate, whilst exsanguination (i.e., the predominant cause of death within the first 24 hours) was found to be significantly decreased in the 1:1:1 group. A higher number of patients in the 1:1:1 group also achieved effective hemostasis than in the 1:1:2 group. Albeit the 1:1:1 group received more plasma and similar amounts of red blood cells units during the first 24 hours, no difference between the two groups could be observed for acute respiratory distress syndrome, multiple organ failure, venous thromboembolism, sepsis and transfusion-related complications. ${ }^{28,29}$

The goal-directed hemostatic resuscitation strategy entails the early goal concept of selective administrating clotting factors, associated with the damage control strategy, aimed to avoid colloid administration during resuscitation. This approach is based on the use of VETs for monitoring the evolution of TIC combined with administration of specific clotting factors (i.e., fibrinogen, prothrombin complex, factor VII or factor XIII) when appropriate and needed. ${ }^{30-33}$

The Copenhagen Concept lies in between the two formerly cited strategies, by proposing early hemostatic resuscitation with fixed erythrocytes:plasma:platelets ratio of $1: 1: 1$, then followed by a more thoughtful administration of clotting factors, mostly guided by results obtained using either TEG or ROTEM. ${ }^{34}$

The European Guidelines suggest an initial administration of fresh frozen plasma (FFP) (Grade 1B recommendation) or fibrinogen (Grade 1C recommendation) in patients with massive bleeding. When further FFP needs to be administered, the guidelines suggest an optimal FFP: red blood cell ratio of at least 1:2 (Grade $2 \mathrm{C}$ recommendation). ${ }^{35}$

\section{Methods of research}

Based on the aforementioned preliminary data, a number of studies have been published on VETs-guided management of severe bleeding in trauma patients. Therefore, the aim of this study is to collect and discuss the available evidence on goal-directed hemostatic resuscitation regarding the clinical management of severe bleeding in trauma patients.

An electronic search was conducted in Medline (PubMed interface) using the keywords "thromboelastography", "TEG", "thromboelastometry", "ROTEM" and "trauma patients", limited to the past 30 years and with no language restriction. Overall, 213 studies could be identified, 43 fulfilled the inclusion criteria and 6 could then be included in meta-analysis. A total number of 37 studies were excluded due to inappropriate patient population or study design (i.e., paediatric or surgical patients, comparison between TEG and rapid-TEG, review articles). Our analysis only included studies with patients aged 18 years or older, major trauma, and needing massive transfusions. After application of these inclusion and exclusion criteria, 6 studies, totalling 1533 patients, could be included in our study. With the only exception of the randomized controlled trial published by Gonzalez et al.,${ }^{30}$ the remaining studies were cross-sectional and retrospective (i.e., groups conventionally managed versus groups treated with goal-directed hemostatic resuscitation). The main endpoints included mortality, need for transfusions, hospital length of stay (LOS) and intensive care unit (ICU) LOS. The characteristics of the 6 studies are summarized in Table $1 .{ }^{30-33,36,37}$

A random-effects model (DerSimonia-Laird method) or a fixed-effects model (Mantel-Haenszel method) were then applied when significant $\left(I^{2} \geq 50 \%\right.$ and $\left.\mathrm{P}<0.1\right)$ or insignificant heterogeneity could be calculated. Heterogeneity was tested by estimating the proportion of between-study inconsistencies due to actual differences among studies rather than differences due to random error or chance, using the $I^{2}$ statistic. 


\section{Results}

The main characteristics of the studies included in this analysis are shown in Table 1. The injury severity score differences of patients included in the 6 studies did not reach statistical significance (Figure 1; 95\% CI -0.157-0.090; $\mathrm{P}=0.597$ ).

Overall, 288 patients died in the 6 studies, 98 of whom in the intervention (i.e., VET-guided management) groups. A significant reduction of death was found in the intervention groups (relative risk, $0.641 ; 95 \%$ confidence interval $[95 \% \mathrm{CI}]$, 95\% CI $0.517-$ 0.795; $\mathrm{P}<0.001$ ) (Figure 2).

Regarding the specific studies, Yin et al. reported a non-significant reduction in transfusion needs (red blood cell, 5 vs 6.5 units, $\mathrm{P}=0.22$; platelets 0 vs 0 units, $\mathrm{P}=0.15$; FFP, 5.7 vs 6.1 units, $\mathrm{P}=0.54)$. A trend toward a greater LOS was found in the interventional group (ICU LOS $12.2 \pm 11.8$ vs $8.1 \pm 5.5$ days, $\mathrm{P}=0.28$;
Hospital LOS $15.6 \pm 12.7$ vs $11.3 \pm 6.2$ days, $\mathrm{P}=0.10) .{ }^{33}$

Schochl et al. failed to find a significant difference in ICU LOS (14.5 vs 14.0 days, $\mathrm{P}=0.95$ ), whilst Hospital LOS was significantly decreased in the intervention group (23 vs 32 days, $\mathrm{P}<0.005$ ). Patients in control group received a median of 6 FFP Units, whilst those in the intervention group received a median of $6 \mathrm{~g}$ of fibrinogen concentrate and $1200 \mathrm{IU}$ of prothrombin complex. Blood transfusion could be avoided in $29 \%$ of patients in the intervention group compared to only $3 \%$ in the control group $(\mathrm{P}<0.001)$. Platelet transfusion was avoided in $91 \%$ of patients in the intervention group compared to $56 \%$ in the control group $(\mathrm{P}<0.001){ }^{31}$

Nardi et al. reported a significant difference between groups only for FFP use $(4.21 \pm 4.61$ vs $8.97 \pm 9.47 \mathrm{U}$., $\mathrm{P}<0.05)$. No other significant difference was found, albeit a trend toward reduced transfusions need was found (red blood cells, $6.5 \pm 4.8$ vs $8.09 \pm 6.7$ U., $\mathrm{P}>0.05$; platelets, $2.68 \pm 4.75$ vs $4.18 \pm 5.9$ U., $\mathrm{P}>0.05$ ). ${ }^{36}$

Table 1. Characteristics and results of the analyzed studies.

\begin{tabular}{|c|c|c|c|c|c|c|c|c|c|}
\hline Study & Method & $\begin{array}{l}\text { Controls/ } \\
\text { Intervention } \\
\text { (n) }\end{array}$ & Test & $\begin{array}{c}\text { ISS } \\
(\text { mean } \pm S D)\end{array}$ & $\begin{array}{l}\text { Mortality } \\
\text { (n) }\end{array}$ & $\begin{array}{c}\mathrm{RBC} \\
\text { (units; mean } \pm \mathrm{SD} \text { ) }\end{array}$ & $\begin{array}{c}\text { PLT } \\
\text { (units; mean } \pm \text { SD) }\end{array}$ & $\begin{array}{c}\text { FFP } \\
\text { (unit; mean } \pm S D \text { ) }\end{array}$ & $\begin{array}{c}\text { ICU LOS } \\
\text { (days; mean } \pm \text { SD) }\end{array}$ \\
\hline $\begin{array}{l}\text { Yin et al., } \\
2014^{33}\end{array}$ & Retrospective & $\begin{array}{l}31 \\
29\end{array}$ & TEG & $\begin{array}{c}14.3 \pm 5.7 \\
16.2 \pm 8\end{array}$ & $\begin{array}{l}2 \\
3\end{array}$ & $\begin{array}{c}6.5(4-14) \\
\text { median } \\
5(3-13)\end{array}$ & $\begin{array}{l}0(0-10) \\
\text { median } \\
0(0-0)\end{array}$ & $\begin{array}{l}6.1(4-10.7) \\
\text { median } \\
5.7(3.4-10)\end{array}$ & $\begin{array}{c}8.1 \pm 5.511 .3 \pm 6.2 \\
12.2 \pm 11.815 .6 \pm 12.7\end{array}$ \\
\hline $\begin{array}{l}\text { Schochl et al., } \\
2011^{31}\end{array}$ & Retrospective & $\begin{array}{c}601 \\
80\end{array}$ & ROTEM & $\begin{array}{c}35.2 \pm 12.5 \\
35 \pm 10.5\end{array}$ & $\begin{array}{c}60 \\
6\end{array}$ & $\begin{array}{l}97 \% \text { pts } \\
71 \% \text { pts }\end{array}$ & $\begin{array}{l}44 \% \mathrm{pts} \\
9 \% \mathrm{pts}\end{array}$ & & $\begin{array}{c}1432 \\
14.523\end{array}$ \\
\hline $\begin{array}{l}\text { Nardi et al., } \\
2015^{36}\end{array}$ & Retrospective & $\begin{array}{c}130 \\
96\end{array}$ & ROTEM & $\begin{array}{c}32.5 \\
33\end{array}$ & $\begin{array}{l}26 \\
13\end{array}$ & $\begin{array}{c}8.09 \pm 6.7 \\
6.5 \pm 4.8\end{array}$ & $\begin{array}{c}4.18 \pm 5.9 \\
2.68 \pm 4.75\end{array}$ & $\begin{array}{l}8.97 \pm 9.47 \\
4.21 \pm 4.61\end{array}$ & \\
\hline $\begin{array}{l}\text { Tapia et al., } \\
2013^{32}\end{array}$ & Retrospective & $\begin{array}{l}124 \\
165\end{array}$ & TEG & $\begin{array}{l}24 \pm 15 \\
23 \pm 14\end{array}$ & $\begin{array}{l}67 \\
55\end{array}$ & & & & \\
\hline $\begin{array}{l}\text { Gonzalez et al., } \\
2016^{30}\end{array}$ & $\begin{array}{l}\text { Randomized } \\
\text { prospective }\end{array}$ & $\begin{array}{l}55 \\
56\end{array}$ & TEG & $\begin{array}{c}33 \\
29.5\end{array}$ & $\begin{array}{l}20 \\
11\end{array}$ & $\begin{array}{l}11(6-16) \\
\text { median } \\
9.5(5-16)\end{array}$ & $\begin{array}{l}1(0-2) \\
\text { median } \\
1(0-2)\end{array}$ & $\begin{array}{l}6(4-9) \\
\text { median } \\
5(3-9)\end{array}$ & \\
\hline $\begin{array}{l}\text { Wang et al., } \\
2017^{37}\end{array}$ & Retrospective & $\begin{array}{l}80 \\
86\end{array}$ & TEG & $\begin{array}{l}32 \\
28\end{array}$ & $\begin{array}{l}15 \\
10\end{array}$ & $\begin{array}{c}9 \pm 10 \\
4 \pm 7\end{array}$ & $\begin{array}{l}2.9 \pm 4.8 \\
0.4 \pm 1.5\end{array}$ & $\begin{array}{l}5 \pm 6 \\
1 \pm 5\end{array}$ & $\begin{array}{c}13.6 \pm 148.8 \pm 10.6 \\
19 \pm 1614 \pm 12\end{array}$ \\
\hline
\end{tabular}

ISS, Injury Severity Score; RBC, red blood cells; PLT, platelets; FFP, fresh frozen plasma; ICU, intensive care unit; LOS, length of stay; pts, patients; TEG, thromboelastogram; ROTEM, thromboelastography.

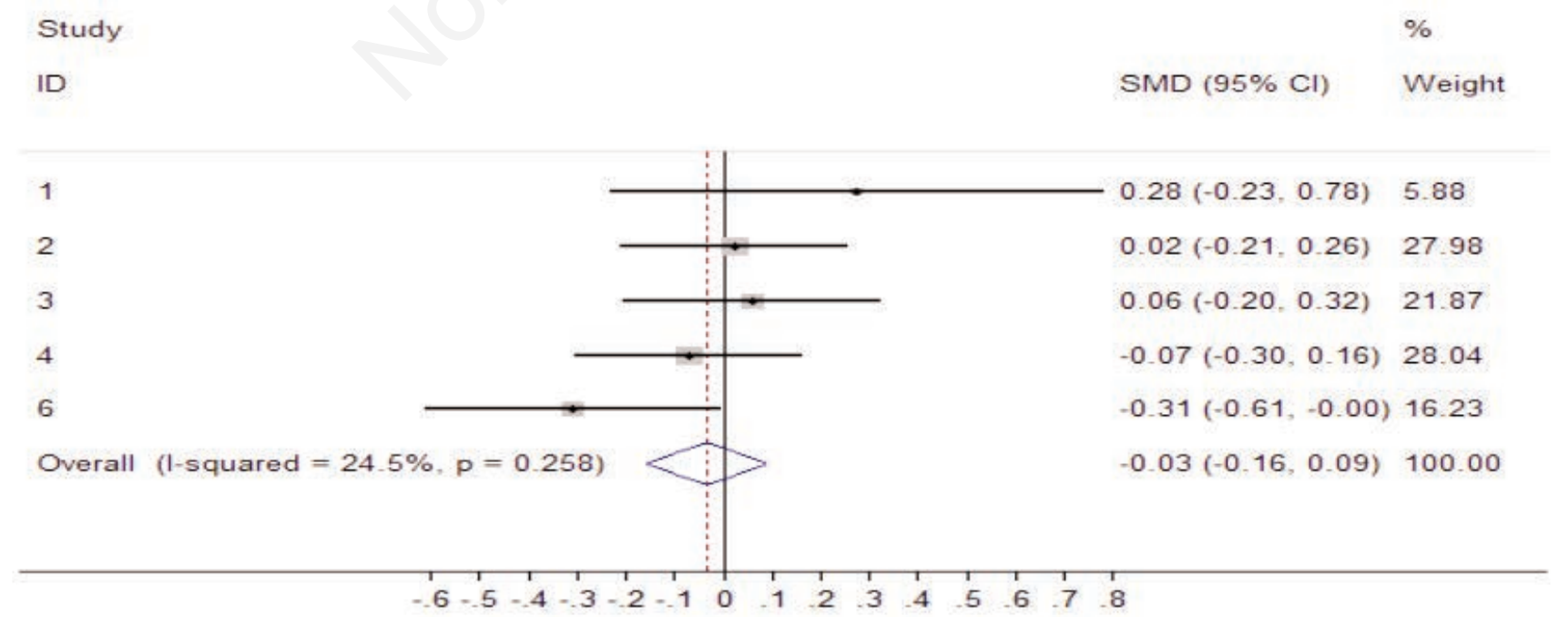

Figure 1. Forest plot of injury severity score. SMD, standard mean difference; CI, confidence interval. 
Unlike the previous studies, Tapia et al. separated blunt from penetrating trauma patients, concluding that TEG-guided resuscitation was similar to standardized massive transfusion protocols in blunt trauma patients receiving 6 units or more of red blood cells and in penetrating trauma patients receiving 10 units or more of red blood cells. Nevertheless, higher mortality was observed with massive transfusion protocols in penetrating trauma patients receiving 10 units or more of red blood cells, thus emphasizing the importance of continuous TEG-guided therapy. This would lead to conclude that a 1:1:1 strategy may not be adequate in all patients. ${ }^{32}$

In the only prospective randomized trial published by Gonzalez et al. (including a total number of 111 patients), patient survival in the TEG group was found to be significantly higher than in the CCTs group. More specifically, 20 deaths could be recorded in the CCTs group (36.4\%) compared to 11 in the TEG group (19.6\%; $\mathrm{P}=0.049)$, respectively. Most deaths occurred within the first 6 hours $(21.8 \%$ in CCTs group vs $7.1 \%$ in TEG group; $\mathrm{P}=0.032$ ). Although CCTs patients needed a similar number of red blood cell units as TEG patients, patients in the CCTs group received more FFP and platelets units in the first 2 hours of resuscitation. ${ }^{30}$

In the last study, Wang et al. ${ }^{37}$ reported a significant difference between the intervention and control groups for all the endpoints studied (red blood cells, $4 \pm 7$ vs $9 \pm 10$ units, $\mathrm{P}<0.01$; platelets, $0.4 \pm 1.5$ vs $2.9 \pm 4.8$ units, $\mathrm{P}<0.01$; FFP, $1 \pm 5$ vs $5 \pm 6$ units, $\mathrm{P}<0.01$; ICU LOS $8.8 \pm 10.6$ vs $13.6 \pm 14$ days, $\mathrm{P}<0.05$; hospital LOS $14 \pm 12$ vs $19 \pm 1$ days, $\mathrm{P}<0.005)$.

\section{Discussion and Conclusions}

The results of this analysis show that up to $36 \%$ lower mortality can be reached in major trauma patients whose treatment is guided by VET than in these conservatively managed with CCTs. The intervention group (i.e., VET-guided treatment) included patients managed according to TEG or ROTEM data, following the so-called goal-directed hemostatic resuscitation. This approach was also associated with a broadly variable (i.e., due to the heterogeneity of the studies) lower use of blood products, thus achieving the goal of optimizing administration of these therapeutic products, which are not completely free from side effects. Beside viral infections, the use of FFP is associated with a higher risk of acute lung injury (transfusion related acute lung injury or acute respiratory distress syndrome), fluid overload, immune system depression. Little dose of FFP is not efficient to completely correct TIC, whilst larger amounts generate a dilutional effect of blood cells, which then needs further transfusion of packed red blood cells. ${ }^{21,38}$

The effectiveness of VETs guidance in resuscitation has been recognized for decades in the area of cardiothoracic surgery and organ transplantation. Regarding massive trauma, only retrospective observational studies have been published so far, except for that of Gonzalez et al. ${ }^{30}$

There is a rather long history on VETs use on clinical practice, which commenced early after the pioneering work of Hellmut Hartert, in 1948, who described the hemostatic potential of whole blood samples using TEG. ${ }^{39}$ The first clinical use of TEG to guide blood component transfusion in trauma populations can be brought back to the Vietnam War, in the late 1950s. ${ }^{40}$

VETs display several advantages compared to CCTs, but are plagued by some limitations. These tests, for example, have heterogeneous sensitivity for diagnosing hyperfibrinolysis. ${ }^{41,42}$ Moreover, they are carried out at standard human body temperature (i.e., $37^{\circ} \mathrm{C}$ ), so that hypothermic patients should be rewarmed. ${ }^{43,44}$ In the hemorragic patient, low hematocrit may worsen bleeding in vivo, but is effective to improve some VETs variables in vitro. VETs results, therefore, should be interpreted according to severity of anemia, hemodilution and some other clinical parameters..$^{45,46}$

Notwithstanding these limitations, our study attempted to provide some reliable evidence on the practical use of VETs for guiding resuscitation in trauma patients. Except for mortality, for which a significant trend toward reduction could be clearly demonstrated, the data of all the others endpoints were largely heterogeneous across the various studies. This emphasize the need of planning

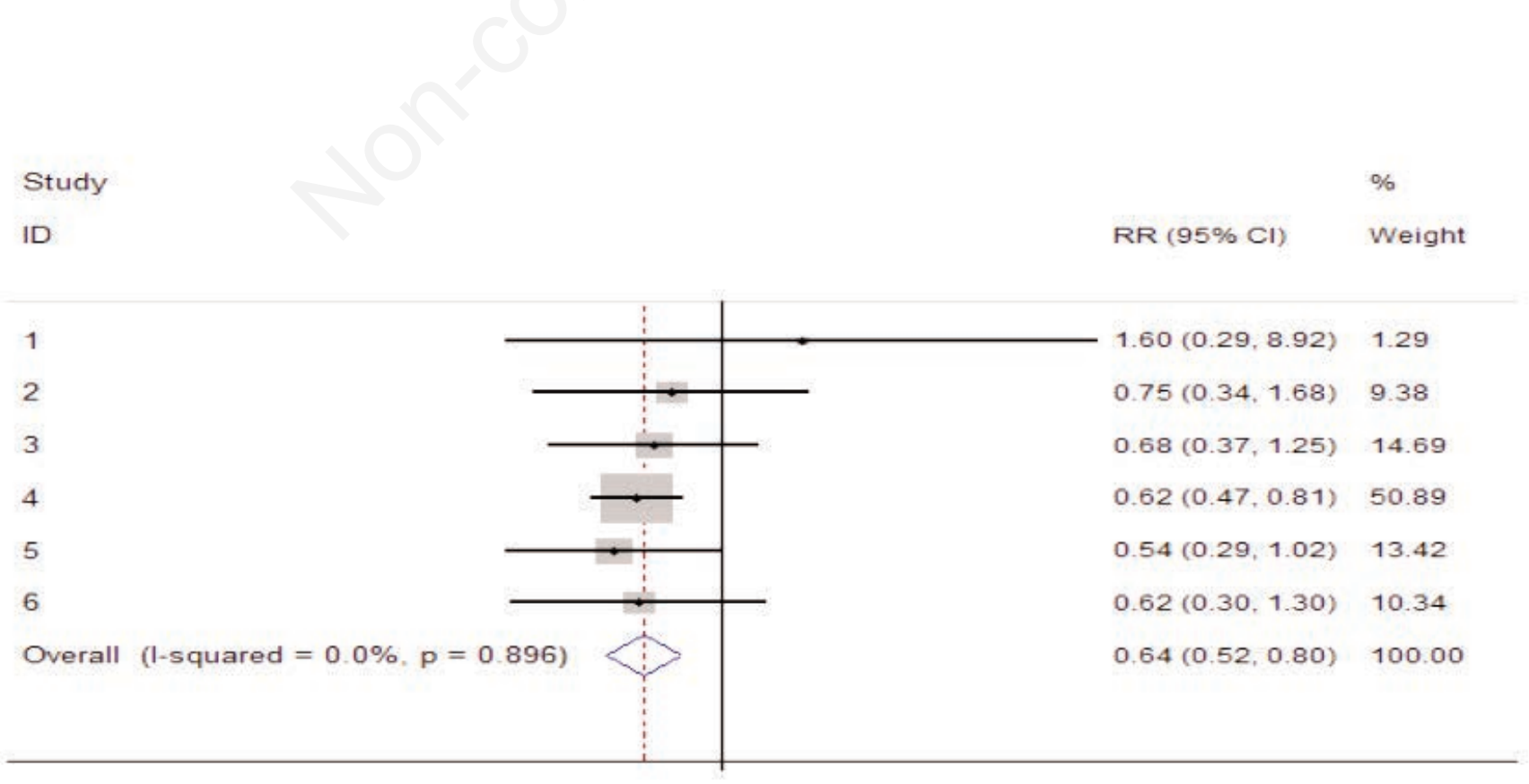

Figure 2. Forest plot mortality. RR, relative risk; CI, confidence interval. 
new and well-designed trials, aimed to better define the optimal strategy for TIC management.

In conclusion, the use of VETs for managing massive trauma patients may be effective for optimizing the administration of blood products and for lowering mortality. However, before VETguided therapeutic management of TIC patients can be widely recommended, their limitations need to be acknowledged and addressed. These typically include quality assurance and availability of trained personnel capable to perform and interpret the test in a typical extra-laboratory environment (e.g., the ICU). However, the use of VET-guided administration of blood components and hemostatic agents for damage control resuscitation is now becoming a more widely accepted strategy for trauma patients. Specific training will be needed for using these tests by emergency physicians, trauma surgeons, anesthesiologists and other trauma-related staff. With only one exception, randomized controlled trials on the use of VETs are substantially lacking in TIC, which may be seen as a serious threat for widespread use of this promising tests in routine management of massive trauma patients.

\section{References}

1. Lozano R, Naghavi M, Foreman K, et al. Global and regional mortality from 235 causes of death for 20 age groups in 1990 and 2010: a systematic analysis for the Global Burden of Disease Study 2010. Lancet 2012;380:2095-128.

2. Murray CJ, Atkinson C, Bhalla K, et al. The state of US health, 1990-2010: burden of diseases, injuries, and risk factors. JAMA 2013;310:591-608.

3. Rhee P, Joseph B, Pandit V, et al. Increasing trauma deaths in the United States. Ann Surg 2014;260:13-21.

4. European Communities. Health statistics - atlas on mortality in the European Union. Available from: http://epp.eurostat. ec.europa.eu/cache/ITY_OFFPUB/KS-30-08-357/EN/KS-3008-357-EN.PDF

5. Tieu BH, Holcomb JB, Schreiber MA. Coagulopathy: its pathophysiology and treatment in the injured patient. World $\mathrm{J}$ Surg 2007;31:1055-64.

6. Cohen MJ. Towards hemostatic resuscitation: the changing understanding of acute traumatic biology, massive bleeding and damage control resuscitation. Surg Clin North Am 2012;92:877-91.

7. Norton R, Kobusingye O. Injuries. N Engl J Med 2013;368: 1723-30.

8. MacKenzie EJ, Rivara FP, Jurkovich GJ, et al. A national evaluation of the effect of trauma-center care on mortality. N Engl J Med 2006;354:366-78.

9. Cannon JW. Hemorrhagic Shock. N Engl J Med 2018;378:370-9.

10. Theusinger OM, Bauling W, Levy JH. Coagulation in trauma. Trends Anaesth Crit Care 2015;5:23-7.

11. Frith D, Goslings J, Gaarder C, et al. Definition and drivers of acute traumatic coagulopathy: clinical and experimental investigations J Thromb Haemost 2010;8:1919-25.

12. Maegele M, Lefering R, Yucel N, et al. Early coagulopathy in multiple injury: an analysis from the german trauma registry on 8724 patients. Injury 2007;38:298-304.

13. Brohi K, Cohen M, Ganter M, et al. Acute traumatic coagulopathy: initiated by hypoperfusion. Modulated through the protein C pathway? Ann Surg 2007;245:812-8.

14. Solomon C, Traintinger S, Ziegler B, et al. Platelet function following trauma: a multiple electrode aggregometry study. Thromb Haemost 2011;106:322-30.

15. Cap A, Hunt B. The pathogenesis of traumatic coagulopathy. Anaesthesia 2015;70:E32-4.

16. Lippi G, Cervellin G. Disseminated intravascular coagulation in trauma injuries. Semin Thromb Hemost 2010;36:378-87.

17. Hess JR, Brohi K, Dutton R, et al. The coagulopathy of trauma: a review of mechanisms. J Trauma 2008;65:748-54.

18. Wafaisade A, Wutzler S, Lefering R, et al. Drivers of acute coagulopathy after severe trauma: a multivariate analysis of 1987 patients. Emerg Med J 2010;27:934-9.

19. Floccard B, Rugeri L, Faure A, et al. Early coagulopathy in trauma patients: an on-scene and hospital admission study. Injury 2012;43:26-32.

20. Brohi K, Cohen MJ, Davenport RA. Acute coagulopathy of trauma: mechanism, identification and effect. Curr Opinion Crit Care 2007;13:680-5.

21. Walsh M, Fritz S, Hake D, et al. Targeted Thromboelastographic (TEG) blood component and pharmacologic hemostatic therapy in traumatic and acquired coagulopathy. Current Drug Targets 2016;17:954-70.

22. Ganter MT, Hofer CK. Coagulation monitoring: current techniques and clinical use of viscoelastic point-of-care coagulation devices. Anesth Analg 2008;106:1366-75.

23. Da Luz LT, Nascimento B, Shankarakutty AK, et al. Effect of thromboelastography (TEG) and rotational thromboelastometry (ROTEM) on diagnosis of coagulopathy, transfusion guidance and mortality in trauma: descriptive systematic review. Crit Care 2014;18:518.

24. Cotton BA, Faz G, Hatch QM, et al. Rapid thromboelastography delivers real-time results taht predict transfusion within 1 hour of admission. J Trauma 2011;71:407-7.

25. Holcomb J, Minei K, Scerbo M, et al. Admission rapid thrombelastography can replace conventional coagulation tests in the emergency department: experience with 1974 consecutive trauma patients. Ann Surg 2012;256:476-86.

26. Schochl H, Voelckel W, Grassetto A, et al. Practical application of point-of-care coagulation testing to guide treatment decisions in trauma. J Trauma Acute Care Surg 2013;6:1587-98.

27. Holcomb JB, del Junco DJ, Fox EE, et al. The Prospective, Observational, Multicenter, Major Trauma Transfusion (PROMMTT) study comparative effectiveness of a time-varying treatment with competing risks. JAMA Surg 2013;148:127-36.

28. Holcomb JB, Tilley BC, Baraniuk S, et al. Transfusion of plasma, platelets, and red blood cells in $1: 1: 1$ vs a $1: 1: 2$ ratio and mortality in patients with severe trauma: the PROPPR randomized clinical trial. JAMA 2015;313:471-82.

29. Moore EE, Moore HB, Chapman MP, et al. Goal-directed hemostatic resuscitation for trauma induced coagulopathy: maintaining homeostasis. J Trauma Acute Care Surg 2018;84:S35-40.

30. Gonzalez E, Moore EE, Moore HB, et al. Goal-directed hemostatic resuscitation of trauma-induced coagulopathy: a pragmatic randomized clinical trial comparing a viscoelastic assay to conventional coagulation assays. Ann Surg 2016;263:10519.

31. Schochl H, Nienaber U, Maegele M, et al. Transfusion in trauma: thromboelastometry-guided coagulation factor concentrate-based therapy versus standard fresh frozen plasma-based therapy. Crit Care 2011;15:R83.

32. Tapia NM, Chang A, Norman M, et al. TEG-guided resuscitation is superior to standardized MTP resuscitation in massively 
transfused penetrating trauma patients. J Trauma Acute Care Surg 2013;74:378-86.

33. Yin J, Zhao Z, Li Y, et al. Goal-directed transfusion protocol via thromboelastography in patients with abdominal trauma: a retrospective study. World J Emerg Surg 2014;9:28.

34. Stensballe J, Ostrowski SR, Johansson PI. Viscoelastic guidance of resuscitation. Curr Opin Anaesthesiol 2014;27:212-8.

35. Spahn D, Bouillon B, Cerny V, et al. Management of bleeding and coagulopathy following major trauma: an updated European guideline. Crit Care 2013;17:R76.

36. Nardi G, Agostini V, Rondinelli B, et al. Trauma-induced coagulopathy: impact of the early coagulation support protocol on blood product consumption, mortality and costs. Crit Care 2015;19:83.

37. Wang H, Robinson RD, Phillips JL, et al. Traumatic abdominal solid organ injury patients might benefit from thromboelastography-guided blood component therapy. J Clin Med Res 2017;9:433-8.

38. Meyer DE, Reynolds JW, Hobbs R, et al. the incidence of transfusion-related acute lung injury at a large, urban tertiary medical center: a decade's experience. Anesth Analg 2018;127:444-9.

39. Hartert H. Blutherinnungsstudien nit der thromboelastographie, einem neuen untersuchungsverfarhren. Klinische
Wochenschrift 1948;26:577-83.

40. Hardaway R, Bredenberg C. Monitoring hematology laboratory values. Care of Wounded in Vietnam. Manhatten, Kansas; 1988. pp 139-220.

41. Raza I, Davenport R, Rourke C, et al. The incidence and magnitude of fibrinolytic activation in trauma patients. $\mathrm{J}$ Thromb Haemost 2013;11:307-14.

42. Schochl H, Voelckel W, Maegele M, et al. Trauma-associated hyperfibrinolysis. Hämostaseologie 2012;32:22-7.

43. Ruzicka J, Stengl M, Bolek L, et al. Hypothermic anticoagulation: testing individual responses to graded severe hypothermia with thromboelastography. Blood Coagul Fibrinolysis 2012;23:285-9.

44. Jeppesen AN, Kirkegaard H, Ilkjær S, et al. Influence of temperature on thromboelastometry and platelet aggregation in cardiac arrest patients undergoing targeted temperature management. Crit Care 2016;20:118.

45. Bolliger D, Seeberger M, Tanaka K. Principles and practice of thromboelastography in clinical coagulation management and transfusion practice. Transfus Med Rev 2012;26:1-13.

46. Spiezia L, Radu C, Marchioro P, et al. Peculiar whole blood rotation thromboelastometry (Rotem) profile in 40 sideropenic anaemia patients. Thromb Haemost 2008;100:1106-10. 